\title{
EFFECT OF STOCKING DENSITY ON THE CULTURE OF SILVER BARB (Barbodes gonionotus) IN FERTILIZED PONDS
}

\author{
Mas Tri Djoko Sunarno*) and Amararatne Yakupitiyage*")
}

\begin{abstract}
The effect of stocking density on the culture of silver barb (Barbodes gonionotus) was evaluated in this experiment. Fingerlings were raised in cages placed in highly fertilized ponds at different densities $\left(0.5,1,2,3,4,5 \mathrm{fish} / \mathrm{m}^{2}\right)$. They were fed on supplementary feed containing $25 \%$ protein and $4.4 \mathrm{kcal}$ gross energy for 92 days. Daily feeding allowance was adjusted at a declining rate with increasing fish size every 23 days. Survival was $87 \%$ to $100 \%$ and comparable for all stocking densities. Growth rate of fish decreased with increasing stocking density. Inversely, total yield of fish significantly increased with increasing stocking density. Apparent feed conversion ratio (FCR) for all treatments was low, ranging from 1.1--1.2. This experiment indicated that a fish density of $4 \mathrm{fish} / \mathrm{m}^{2}$ was optimal for silver barb cultured in a highly fertilized pond.
\end{abstract}

KEYWORDS: silver barb, tawes, Barbodes gonionotus, density, feed, pond

\section{INTRODUCTION}

Herbivorous fish species like silver barb or tawes (Barbodes gonionotus) play a significant role in supplying nutrients in many Asian countries. Semi-intensive pond systems are widely used to produce fish. However, fish production is low (De Silva \& Davy, 1992). This may be caused by inefficient utilization of nutrients available in ponds by fish.

The growth of fish in ponds is related to environmental conditions and food. When the amount of available food is higher than that required by fish, it allows the fish to grow at maximum potential rate. To increase fish weight or biomass, more food is required and the growth will decrease and/or cease when available food is below the fish requirement. Adding fertilizers and/ or supplementary feed will increase fish growth/biomass. In this situation, water quality condition, particularly oxygen concentration, and toxic materials produced by excess fertilizers/feed and fish metabolism will limit fish growth. This means that an adequate stocking density of pond to get appropriate fish size at yield should be considered (Huet, 1986; Schroeder, 1980) to attain maximum growth and optimum yield of fish.

Determination of the optimum fish density requires better knowledge of the amount of available natural food in the pond and the relationships between the amount of food, fish density, individual growth rate and yield (Hepher, 1979; Huet, 1986). Ardiwinata (1981) reported that in Indonesia, silver barb was usually raised in semiintensive ponds at a stocking density of 4,000-7,000 fish/ha for 4-6 months to produce table fish (more than 50g). In Thailand, stocking density of 20,000-30,000 fish/ha was used for silver barb cultured in semi-intensive ponds (Tatong et al., 1980). Filter feeder tilapia could be raised in fertilized pond at density of $5 \mathrm{fish} / \mathrm{m}^{2}$ without feeding (Colman et al., 1990).

The relationship between feed quality and fish yield was evaluated by Hepher (1975) for common carp (Cyprinus carpio). The highest yield of the fish was obtained at $800 \mathrm{~kg} / \mathrm{ha}$ for fish fed on cereal grain and formulated feed containing $22.5 \%$ protein. Increasing fish yield up to $1,400 \mathrm{~kg} / \mathrm{ha}$, was observed for fish fed on pelleted feed with $27.5 \%$ protein. However, such information is not available for silver barb. Therefore, this experiment was carried out to evaluate the effect of stocking density on the culture of silver barb raised in semi-intensive ponds.

\section{MATERIALS AND METHODS}

The experiment was carried out at the Asian Institute of Technology, located near Bangkok. Six earthen ponds of $200 \mathrm{~m}^{2}$ were used to set $5.25 \times 3.5 \times 1.75 \mathrm{~m}$ (32 $\mathrm{m}^{3}$ or $18 \mathrm{~m}^{2}$ surface area) net cages. The ponds were dried for a week and then limed using $\mathrm{Ca}(\mathrm{OH})_{2}$ at $625 \mathrm{~kg} / \mathrm{ha}$. When dry, three net cages were placed in each pond. Ponds were filled with canal water to reach $1 \mathrm{~m}$ depth. This depth was maintained along the experimental period. Urea, TSP and chicken manure were applied to all experimental ponds every 3 days at respective rates of $3 \mathrm{~kg} \mathrm{~N}, 1.5 \mathrm{~kg} \mathrm{P}$ and $10 \mathrm{~kg}$ chicken manure/ha/day

Silver barb fry purchased from a hatchery were nursed in ponds and fed commercial feed containing

Researcher at Research Institute for Openwaters Fisheries, JI. Beringin No. 308 Mariana, P.O. Box 1125 Palembang, Indonesia

") Agricultural and Aquatic System Program, School of Environment, Resources and Development, Asian Institute of Technology, P.O. Box 4 Klong Luang, Pathumthani 12120, Thailand 
$30 \%$ protein ad libitum twice a day in the morning and late afternoon for 45 days. Thereafter, 1,000 fish were selected and acclimatized to experimental conditions for a week.

Acclimated fish were randomly distributed among 18 cages at stocking rates of $0.5,1.0,2.0,3.0,4$, and $5 \mathrm{fish} / \mathrm{m}^{2}$ or $9,18,36,54,72$, and $90 \mathrm{fish} / \mathrm{cage}$, respectively. Individual total length and weight of fish at each cage were measured, and samples of fish were taken for proximate analysis of their carcasses. Fish that died in the first week of fish culture were considered to be the result of handling and were replaced with fish of the same size taken from same batch to maintain a constant stocking rate. During that period, fish mortality was observed daily.

Experimental feed was formulated using fish meal, soybean meal, rice bran, cassava starch, corn oil, fish oil, and mineral premix. The feed contained $25 \%$ protein and $4.4 \mathrm{kcal}$ gross energy (Table 1). The feed was given to the fish twice a day, i.e. in the morning (09.00-10.00) and in the afternoon (17.00-18.00) for 92 days. Daily feeding allowance of fish was adjusted after fish sampling using the feeding standard in Table 2.

The growth of fish was observed by weighing fish every three weeks. At harvest, individual total length and weight of fish from each cage were recorded. Fish samples from each cage were taken at the end of the experiment. Dissolved oxygen, ammonia- $\mathrm{N}$, alkalinity, $\mathrm{pH}$, chlorophyll-a, total suspended solids (TSS), and water temperature (APHA, 1975) were observed every three weeks. Water samples were taken from the water column using a PVC water column sampler.

Data of growth, survival rate, yield, feed and protein intake and utilization and fish carcass composition of silver barb from different treatments were tested using one way ANOVA and followed by the Least Sig-

Table 1. Composition of feed used in the experiment

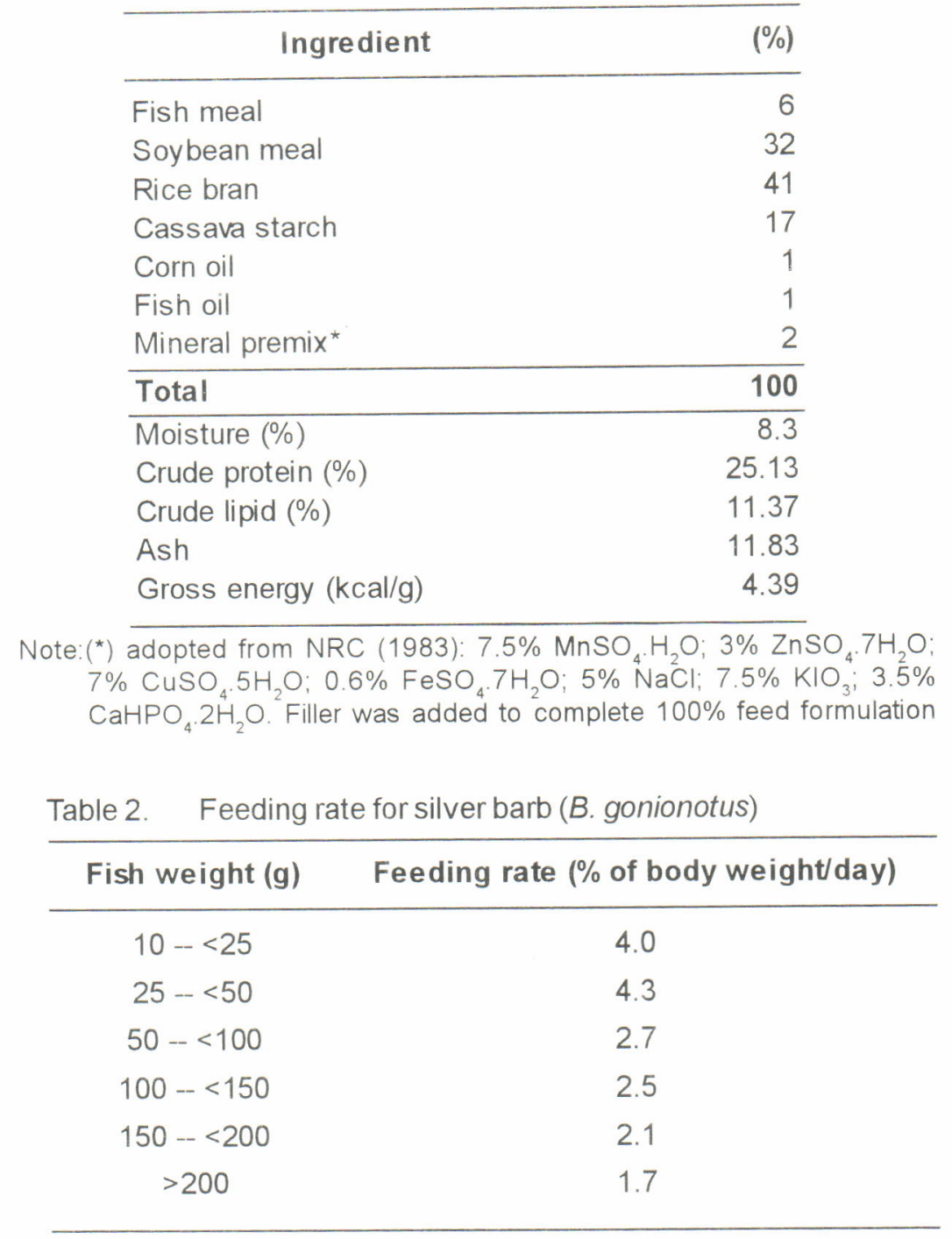


nificant Difference test. Regression analysis was done to determine correlation between variables.

\section{RESULTS}

Growth, survival, and yield of silver barb cultured at different stocking densities are presented in Table 3. Mean weight of fish stocked at different densities are presented in Fig. 1. The mean weight of silver barb at different stocking rates up to Day-23 was comparable, but thereafter stocking densities of 3-5 fish/ $\mathrm{m}^{2}$ resulted in the same mean weight which was smaller than at lower stocking densities. Decrease in mean weight was observed for fish stocked at a rate of $2 \mathrm{fish} / \mathrm{m}^{2}$ at Day-69. However, the mean weight at low stocking density of 0.5 and $1 \mathrm{fish} / \mathrm{m}^{2}$ increased linearly up to the end of culture period. At harvest, the mean weight of fish ranged from $127 \mathrm{~g}$ to $183 \mathrm{~g}$ for high to low stocking density respectively. Survival rate was comparable, ranging from $87.0 \%$ to $100 \%$.

ANOVA of daily weight gain (DWG) of silver barb indicated that the effect of stocking density was significant $(P<0.01)$. The highest DWG $(1.9 \mathrm{~g} / \mathrm{day})$ was found in fish stocked at low density of $0.5 \mathrm{fish} / \mathrm{m}^{2}$. Increase in stocking density linearly decreased DWG as given in the following equation (Fig. 2): DWG(g/ day) $=1.92-0.13 X, r^{2}=0.75$. Effect of stocking densities on specific growth rate (SGR) of silver barb was significant $(P<0.01)$. SGR at stocking densities of 0.5 $2 \mathrm{fish} / \mathrm{m}^{2}$ (2.9\%/day to $2.8 \% /$ day) was not significantly different and higher than that in $3-5 \mathrm{fish} / \mathrm{m}^{2}(2.61 \%$ / day to $2.76 \%$ /day).

A significant effect of stocking density on fish yield of silver barb was observed $(P<0.01)$. Gross yield of fish showed an increasing rate with increasing stocking densities from $0.5 \mathrm{fish} / \mathrm{m}^{2}$ to $5 \mathrm{fish} / \mathrm{m}^{2}$. Extrapolated net yield of silver barb in this study indicated that net yield significantly increased with increasing stocking densities as given in the following equation: Net yield $\left(\mathrm{g} / \mathrm{m}^{2} /\right.$ day $)=0.57+1.08 \mathrm{X}, \mathrm{r}^{2}=0.96$ (Fig. 3)

The relative daily feed intake was not significantly affected by stocking density $(P>0.05)$. The daily feeding rate of fish at any stocking density ranged from $11.3 \%$ to $13.2 \%$ of body weight. The apparent feed conversion ratio (FCR) of silver barb was significantly affected by stocking density $(P<0.01)$. Apparent FCR linearly increased with increasing stocking densities as given in the following equation: Apparent FCR $=1.06+$ $0.055 \mathrm{X}, \mathrm{r}^{2}=0.70$. Protein content in carcasses was

Table 3. Summary results of the effect of stocking density on culture of silver barb (B. gonionotus)

\begin{tabular}{|c|c|c|c|c|c|c|}
\hline \multirow{2}{*}{ Indices } & \multicolumn{6}{|c|}{ Stocking density (fish/m ${ }^{2}$ ) } \\
\hline & 0.5 & 1 & 2 & 3 & 4 & 5 \\
\hline Initial weight (g) & $\begin{array}{l}13.3 \\
(0.3)\end{array}$ & $\begin{array}{l}12.3 \\
(1.6)\end{array}$ & $\begin{array}{l}12.2 \\
(1.3)\end{array}$ & $\begin{array}{c}12 \\
(1.3)\end{array}$ & $\begin{array}{l}11.8 \\
(0.4)\end{array}$ & $\begin{array}{l}12.1 \\
(0.7)\end{array}$ \\
\hline Final weight (g) & $\begin{array}{l}182.6^{a} \\
(13.1)\end{array}$ & $\begin{array}{c}176.6^{a b} \\
(18.7)\end{array}$ & $\begin{array}{l}156.2^{b} \\
(21.7)\end{array}$ & $\begin{array}{c}143.4^{\mathrm{b}} \\
(7.8)\end{array}$ & $\begin{array}{l}141.7^{b} \\
(5.6)\end{array}$ & $\begin{array}{c}127.0^{\circ} \\
(8.2)\end{array}$ \\
\hline Sunival rate (\%) & $\begin{array}{c}100.0^{a} \\
(0.0)\end{array}$ & $\begin{array}{l}87.0^{a} \\
(14.3)\end{array}$ & $\begin{array}{l}96.3^{\mathrm{a}} \\
(3.6)\end{array}$ & $\begin{array}{l}90.7^{a} \\
(10.9)\end{array}$ & $\begin{array}{l}93.5^{a} \\
(5.0)\end{array}$ & $\begin{array}{l}90.4^{a} \\
(7.2)\end{array}$ \\
\hline $\begin{array}{l}\text { Daily weigh gain } \\
\text { (g/day) }\end{array}$ & $\begin{array}{l}1.88^{a} \\
(0.14)\end{array}$ & $\begin{array}{l}1.83^{\mathrm{ab}} \\
(0.22)\end{array}$ & $\begin{array}{l}1.60^{b} \\
(0.23)\end{array}$ & $\begin{array}{l}1.46^{b} \\
(0.06)\end{array}$ & $\begin{array}{l}1.44^{\mathrm{C}} \\
(0.06)\end{array}$ & $\begin{array}{l}1.28^{\mathrm{c}} \\
(0.09)\end{array}$ \\
\hline $\begin{array}{l}\text { Specific growth } \\
\text { rate (\%/day) }\end{array}$ & $\begin{array}{l}2.91^{a} \\
(0.07)\end{array}$ & $\begin{array}{l}2.97^{a} \\
(0.26)\end{array}$ & $\begin{array}{l}2.83^{a} \\
(0.15)\end{array}$ & $\begin{array}{l}2.76^{b} \\
(0.07)\end{array}$ & $\begin{array}{l}2.76^{b} \\
(0.04)\end{array}$ & $\begin{array}{l}2.61^{\mathrm{C}} \\
(0.04)\end{array}$ \\
\hline $\begin{array}{l}\text { Net yield } \\
\left(\mathrm{g} / \mathrm{m}^{2} / \text { day }\right)\end{array}$ & $\begin{array}{l}0.94^{a} \\
(0.07)\end{array}$ & $\begin{array}{l}1.56^{\mathrm{a}} \\
(0.14)\end{array}$ & $\begin{array}{l}3.08^{\mathrm{b}} \\
(0.54)\end{array}$ & $\begin{array}{l}3.94^{\mathrm{C}} \\
(0.54)\end{array}$ & $\begin{array}{l}5.36^{\complement} \\
(0.42)\end{array}$ & $\begin{array}{l}5.69^{d} \\
(0.30)\end{array}$ \\
\hline $\begin{array}{l}\text { Feed intake } \\
\text { (g/kgBW/day) }\end{array}$ & $\begin{array}{l}11.32^{a} \\
(0.16)\end{array}$ & $\begin{array}{l}11.28^{a} \\
(1.29)\end{array}$ & $\begin{array}{l}11.37^{a} \\
(0.35)\end{array}$ & $\begin{array}{l}12.11^{a} \\
(1.47)\end{array}$ & $\begin{array}{l}12.37^{a} \\
(2.03)\end{array}$ & $\begin{array}{l}13.12^{\mathrm{a}} \\
(1.06)\end{array}$ \\
\hline AFCR & $\begin{array}{l}1.11^{\mathrm{a}} \\
(0.02)\end{array}$ & $\begin{array}{l}1.12^{a} \\
(0.01)\end{array}$ & $\begin{array}{l}1.12^{\mathrm{a}} \\
(0.06)\end{array}$ & $\begin{array}{l}1.22^{\mathrm{ab}} \\
(0.14)\end{array}$ & $\begin{array}{l}1.28^{b} \\
(0.03)\end{array}$ & $\begin{array}{l}1.34^{b} \\
(1.07)\end{array}$ \\
\hline $\begin{array}{l}\text { Carcass protein } \\
\text { at harvest }(\%)\end{array}$ & $\begin{array}{l}65.85^{\mathrm{a}} \\
(1.32)\end{array}$ & $\begin{array}{l}68.28^{a b} \\
(3.41)\end{array}$ & $\begin{array}{c}68.95^{a b} \\
(0.63)\end{array}$ & $\begin{array}{l}69.48^{b} \\
(3.18)\end{array}$ & $\begin{array}{l}68.93^{a} \\
(0.11)\end{array}$ & $\begin{array}{l}70.98^{b} \\
(3.47)\end{array}$ \\
\hline $\begin{array}{l}\text { Carcass fat at } \\
\text { harvest }(\%)\end{array}$ & $\begin{array}{l}23.84^{b} \\
(1.85)\end{array}$ & $\begin{array}{l}20.24^{a} \\
(0.92)\end{array}$ & $\begin{array}{l}20.34^{a} \\
(0.92)\end{array}$ & $\begin{array}{l}20.76^{a} \\
(3.25)\end{array}$ & $\begin{array}{l}20.03^{a} \\
(0.11)\end{array}$ & $\begin{array}{l}20.13^{a} \\
(3.73)\end{array}$ \\
\hline
\end{tabular}

Note: Values in the same row having the same letter are not significantly different; Values in brackets are SE, carcass protein and fat at stocking were $69.7 \%$ and $15.7 \%$ on dry basis respectively. 


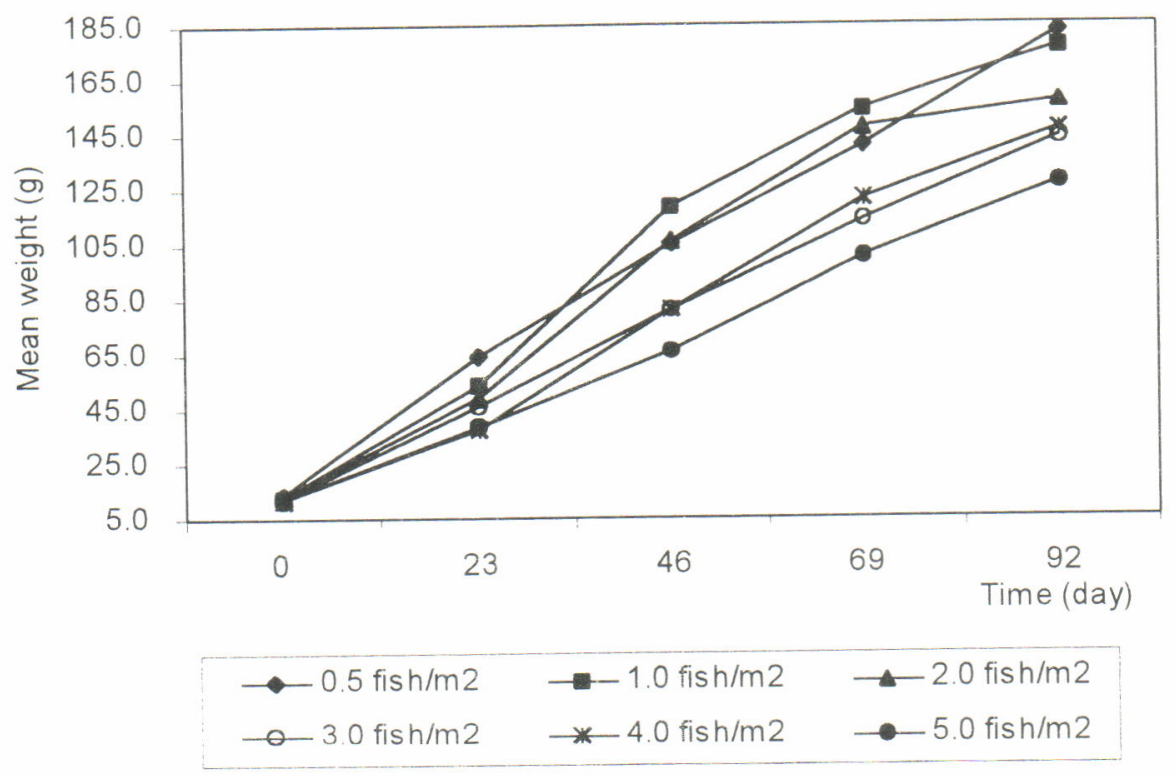

Fig. 1. Mean weight of silver barb (B. gonionotus) at different densities during the culture period

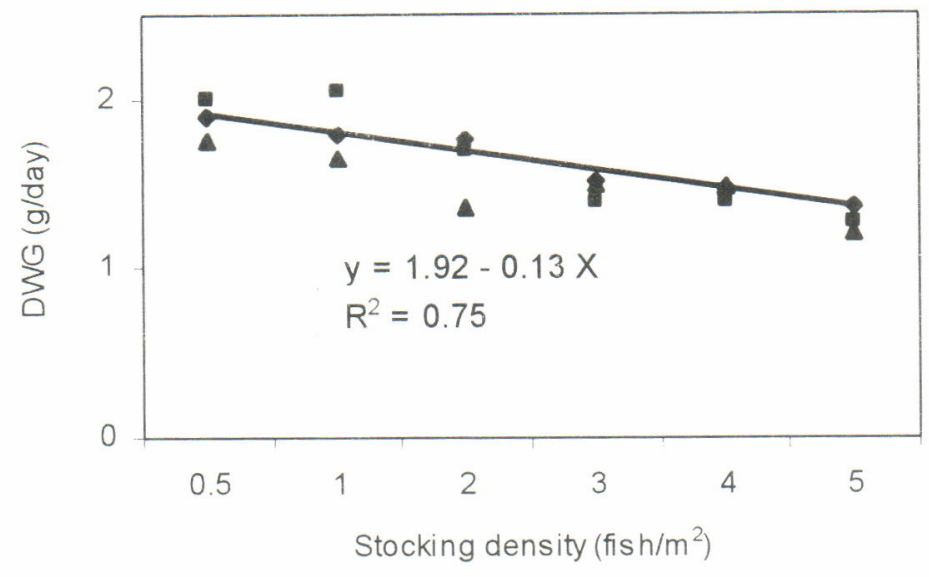

Fig. 2. Relationship between density and daily weight gain (DWG) of silver barb ( $B$. gonionotus) in fertilized ponds

comparable for all treatments. High fat content was observed in the treatment of $0.5 \mathrm{fish} / \mathrm{m}^{2}$, thereafter, increase in stocking density did not affect body fat content.

All observed water quality parameters in different ponds were comparable (Table 4). The lowest dissolved oxygen (DO) concentration was about $2 \mathrm{mg} / \mathrm{L}$. Water temperature of about $30^{\circ} \mathrm{C}$ was optimum for tropical fish culture and its fluctuation in each pond was similar. Total alkalinity tended to increase with time. The $\mathrm{pH}$ ranged from 6 to 9 . Total ammonia- $\mathrm{N}$ concentration was in the normal range for fish and there was no significant effect of different inputs of feed on increasing total ammonia-N. Chlorophyll-a concentration tended to increase at the latter part of the culture period.

\section{DISCUSSION}

One of the most important factors of pond management practices is the biomass of fish. A variety of criteria could be used to assess optimum stocking rate. The higher growth rate at low densities enhances the market value of individual silver barb; however, the yield per unit area may be relative low. The growth, survival, yield and feed conversion ratio may be the best criteria to determine optimum stocking density of fish cultured with a feeding system. 


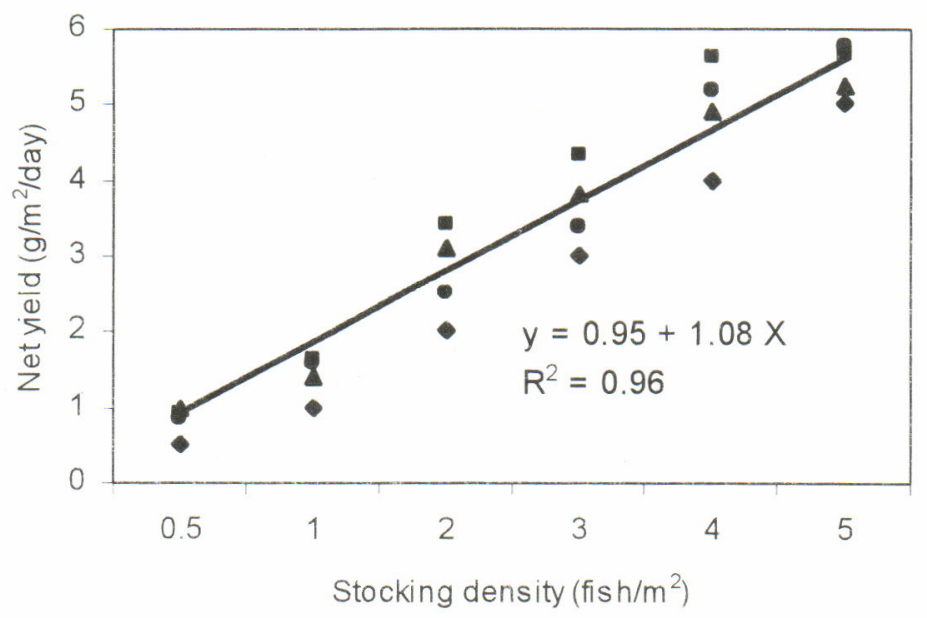

Fig. 3. Relationship between stocking density and net yield of silver barb (B. gonionotus) in fertilized ponds

Table 4. Observed water quality parameters of ponds for silver barb (B. gonionotus) at different stocking densities

\begin{tabular}{|c|c|c|c|c|c|c|}
\hline \multirow{2}{*}{ Parameters } & \multicolumn{6}{|c|}{ Stocking density (fish $/ \mathrm{m}^{2}$ ) } \\
\hline & 0.5 & 1 & 2 & 3 & 4 & 5 \\
\hline$D O(m g / L)$ & $2.2-7.3$ & $2.0-8.3$ & $2.5-7.7$ & $2.2-8.3$ & $2.0-7.8$ & $2.0-8.5$ \\
\hline Temperature $\left({ }^{\circ} \mathrm{C}\right)$ & $22.9-31.0$ & $22.9-31.1$ & $22.9-31.0$ & $22.8-31.0$ & $23.2-31.0$ & $23.2-31.1$ \\
\hline $\mathrm{pH}$ & $6.5-9.0$ & $6.8-9.0$ & $6.6-8.6$ & $6.5-9.5$ & $6.9-8.5$ & $6.3-8.4$ \\
\hline $\mathrm{NH}_{3}-\mathrm{N}(\mathrm{mg} / \mathrm{L})$ & $0.21-1.12$ & $0.26-0.87$ & $0.12-0.84$ & $0.23-0.95$ & $0.12-1.21$ & $0.23-1.02$ \\
\hline Alkalinity (mg CaCO${ }_{3} / \mathrm{L} \mathrm{eq}$ ) & $25.0-97.5$ & $30.3-107.4$ & $22.2-105.5$ & $27.4-116.7$ & $19.6-129.9$ & $20.6-120.8$ \\
\hline Chlorophyll- $\alpha\left(\mathrm{mg} / \mathrm{m}^{3}\right)$ & $20.6-69.4$ & $20.4-87.4$ & $23.4-75.4$ & $26.0-80.8$ & $20.7-100.3$ & $20.7-100.4$ \\
\hline
\end{tabular}

This study has demonstrated that silver barb fingerlings can be reared to market size with mean weight ranging from $127 \mathrm{~g}$ to $183 \mathrm{~g}$ in three months under semi-intensive conditions. The high (about 183 g), medium (about $150 \mathrm{~g}$ ), and low (127 g) mean harvested weights were observed for stocking density of $0.5,2-4$, and $5 \mathrm{fish} / \mathrm{m}^{2}$, respectively. These results were better than silver barb culture practices in ponds as mentioned by Ardiwinata (1981) which reported that under semi-intensive conditions, silver barb reached marketable size (about $60 \mathrm{~g}$ ) within 6 months. High mean harvested weight in this study is related to management of feed and feeding for silver barb instead of feed composition. The survival rate of silver barb was comparable for all stocking densities, ranging from $87 \%$ to $100 \%$ and was satisfactory for fish culture in ponds. Reduction in fish number for all cages was mainly caused by fish escaping from the cages and/ or handling effects at fish sampling. In addition, the small loss of silver barb may also be attributed to bird predation. There were no water quality problems during the experimental period and observed water quality parameters were within the optimal range for fish growth. This implies that effect of loading organic material from both feed and fish metabolism is not significant.

A fish pond can only support a certain biomass of fish because of its limited space and the availability of natural food. If available nutrient in ponds is higher than or equal to the fish requirement, fish grow at the maximum potential rate. The rate of growth decreases when fish biomass increases. Hepher (1975) stated that there was a high interrelation between stocking rate, individual growth rate and the size of fish stocked for common carp in ponds. When stocking rate is low, each fish gets adequate nutrients (both natural food and/or supplementary feed) from the pond to maintain maximum growth rate. The bigger the fish, the higher its maximum growth rate attained when 
sufficient food is available. Low stocking rate will maintain potential maximum growth rate. Increase in stocking rate inhibits individual growth rate. The growth rate decreased significantly with higher densities at similar feeding regimes (Holm et al., 1990). This study showed that growth rate of silver barb decreased linearly with increasing stocking rate from 0.5 to 5 fish/ $\mathrm{m}^{2}$. The highest growth rate of silver barb at lowest stocking densities is probably due to the significant role of natural food available in ponds. High food availability has been shown to compensate partly for negative effects of stocking density on growth of rainbow trout (Holm et al., 1990). Data of relative feed intake support this pattern of growth rate of fish indicating that each fish gets a similar amount of supplementary feed (about $11 \mathrm{~g} / \mathrm{kg}$ body weight, BW/day). This shows that silver barb in ponds obtain nutrients from natural food and/or supplementary feed. Decrease in growth rate at increasing stocking rate may result from increased energy demand for social interactions. High level of social effect interactions may effect energy expenditure, resulting in elevated metabolic rates (Jobling, 1981). Stress also affects the growth rate of fish.

Growth rate was high at low stocking density of $0.5-2 \mathrm{fish} / \mathrm{m}^{2}$ (2.9\%/day). The lowest growth rate was observed at the highest stocking density of $5 \mathrm{fish} / \mathrm{m}^{2}$ ( $2.6 \% /$ day). Stocking density between 3 and 4 fish/ $\mathrm{m}^{2}$ resulted in a modest growth rate of $2.8 \% / d a y$. The growth performance of fish in the present study was lower than in the previous experiment. Differences in growth rate may be related to differences in experimental condition.

Differences in harvested weight of silver barb and similarity in survival rate resulted in differences in fish yield at different stocking densities. Gross yield (kg/ cage) of silver barb increased with increasing stocking densities. The highest gross yield was observed at high stocking density of $5 \mathrm{fish} / \mathrm{m}^{2}$ (10 kg/cage or $5.5 \mathrm{ton} / \mathrm{ha}$ ). Hepher (1979) stated that above a standing crop of 2.4 tons/ha, deficiency of dietary vitamin develops in carp culture. However, it was not observed in this study. Net yield in pond area for high stocking density $\left(5 \mathrm{fish} / \mathrm{m}^{2}\right)$ was $5.7 \mathrm{~g} / \mathrm{m}^{2} /$ day. This yield subsequently decreased at 3-4 fish $/ \mathrm{m}^{2}(4.5 \mathrm{~g} / \mathrm{ha} / \mathrm{day})$ and $2 \mathrm{fish} / \mathrm{m}^{2}(3.1 \mathrm{~g} / \mathrm{ha} /$ day $)$ and $0.5-1 \mathrm{fish} / \mathrm{m}^{2}(1.3 \mathrm{~g} / \mathrm{ha} /$ day) stocking densities. The yield of silver barb in the present study was lower than that of tilapia (about 70 $\mathrm{kg} / \mathrm{ha} /$ day) raised in pond with supplemental feed (Wohlfart and Hulata, 1987).

Hepher (1990) stated that apparent feed conversion ratio (FCR) increased with increasing fish biomass. In the present study, apparent FCR of silver barb linearly increased with increasing stocking rate. Increase in fish biomass resulted in increasing feed re- quirement to maintain fast growth. However, this study showed that apparent FCR had narrow differences, ranging from 1.1--1.2. The highest apparent FCR was observed in stocking rates of 4-5 fish $/ \mathrm{m}^{2}$. All values of FCR for silver barb were satisfactory for commercial fish culture. Lovell (1989) stated that FCR for commercial channel catfish culture was about 2. Low FCR indicates that natural food plays an important role in the supply of protein and energy for fish. Analysis of fish carcasses at harvest indicates that low stocking densities resulted in low protein content and high fat content. This may indicate that excess energy may be formed in ponds treated by high fertilization and feeding and stocked with low stocking density. Availble natural food in the pond may satisfy the energy requirement for fish, so feed energy may be deposited as fat body.

Based on harvested fish weight and FCR, it can be concluded that silver barb could be raised at stocking densities as high as $4 \mathrm{fish} / \mathrm{m}^{2}$ and daily feeding allowance could be adjusted accordingly to fish weight. This culture system could yield silver barb with mean harvested weight, yield and feed conversion efficiency of $150 \mathrm{~g}$ and $5.4 \mathrm{~g} / \mathrm{ha} /$ day, 1.1 , respectively.

\section{REFERENCES}

APHA. 1975. Standard Methods for Examinations of Water and Wastewater. Fifteenth Ed. APHA Inc., New York.

Ardiwinata, R.O. 1981. Seri Pemeliharaan Ikan II. Budidaya Ikan Silver Barb. Sumur Bandung, Bandung, Indonesia

Colman, J.A., B. Edwards, M. Yomchinda, and C. Pacharaprakiti. 1990. Extending the limits of fish production in manured static-water ponds. Aquaculture, 89: $27-41$.

De Silva, S.S. and F.B. Davy. 1992. Fish nutrition research for semi-intensive culture systems in Asia. Asian Fisheries Science, 5: 129--144

Hepher, B. 1975. Supplementary feeding fish culture, Proc. $9^{\text {th }}$ Int. Congr. Nutrition, Mexico 1972, 3: 183-198

Hepher, B. 1979. Supplementary diets and related problems in fish culture. In: J.E. Halver and K. Tiews (Eds.). Finfish Nutrition and Fishfeed Technology. Vol. I. Heenaman, Berlin, Germany. p: 343--347

Holm, J.C., T. Refstie, and S. Bo. 1990. The effect of fish density and feeding regimes on individual growth rate and mortality in rainbow trout (Oncorhynchus mykiss). Aquaculture, 89: 225--232.

Huet, M. 1986. Textbook of Fish Culture, Breeding and Cultivation of Fish. Second Edition. Fishing News Books Ltd, Farnham, Surrey, England

Jobling, M.A. 1981. The influence of feeding on the metabolic rate of fishes: A short review. J. Fish. Biol., 18 . 385--400 
Lovell, T. 1989. Nutrition and Feeding of Fish. Van Nostrand Reinhold, New York.

NRC. 1983. Nutrient Requirements of Warmwater Fishes and Shellfishes. Rev. Ed. Nat. Acad. Sci. Washington D.C

Schroeder, G.L. 1980. Fish farming in manure loaded ponds in R.S.V. Pullin and Z.H. Shehadeh (Eds.) Integrated Agriculture-Aquaculture Use Farming Systems. Proceeding of The ICLARM-SEARCA Conference on Integrated Agriculture-Aquaculture Farming Systems, Manila, Philippines 6-9 August 1979 ICLRAM-Southeast Asian Regional Center for Gradu- ate Study And Research in Agriculture, Manila, Philippines. p: 73--98.

Tatong, A., W. Thawornnan, and J. Khuntong. 1980. Induces spawning and culturing of pla ta pian khao (Barbordes gonionotus Bleeker). The Third Training Course 11 June - 30 July 1980. NIFI, Bangkok, Thailand

Wohlfarth, G.W. and G. Hulata. 1987. Use of manures in aquaculture. In: D.J.W. Moriarty and R.S.V. Pullin (Eds.) Detritus and microbial ecology in aquaculture ICLRAM Conference Proceedings 14, 420B. ICLARM, Manila, Philippines. p. 353--367. 
